\title{
MINERALOGIA, PETROGRAFIA E GEOLOGIA DO KIMBERLITO LIMEIRA E INTRUSÕES ASSOCIADAS, MUNICÍPIO DE MONTE CARMELO, MINAS GERAIS*
}

D.P.Svisero

M.N.C.Ulbrich

As diatremas Limeira, localizadas $26 \mathrm{~km}$ a norte da cidade de Monte Carmelo (MG), são intrusivas em granitos cataclasados do Grupo Araxá. O corpo maior, Limeira 1, é um kimberlito de formato piriforme, com diâmetro principal de $200 \mathrm{~m}$ na direção NW-SE. Apresenta-se coberto por solo argiloso avermelhado que contrasta com o solo cinza claro das encaixantes graníticas, aflorando em um vale perene que corta o diatrema de SW para NE, e na forma de solo de alteração em vales menores. A rocha é cinza escura e possui a textura inequigranular característica dos kimberlitos resultante da presença de 30 a $35 \%$ de olivina em duas gerações distintas: a) macrocristais arredondados de 0,5 a $8 \mathrm{~mm}$, e b) microfenocristais subidiomórficos em matriz constituída por monticellita, espinélio, ilmenita, perovskita, calcita, serpentina e apatita. Macrocristais de flogopita, ilmenita e cromita ocorrem em quantidades subordinadas. A mineralogia e a textura da rocha indicam que se trata de um monticellita kimberlito do tipo I de fácies hipoabissal. Xenólitos mantélicos de até 15 cm de dunito, harzburgito e espinélio Iherzolito são relativamente abundantes. Clastos de calcita de coloração branca, rosa e castanha são comuns. Outros enclaves encontrados no kimberlito são: a) rochas do embasamento, escassos; b) autólitos de kimberlito de granulação mais fina com estruturas de segregação de calcita, e c) enclaves de rochas do corpo Limeira 2.

A segunda intrusão, Limeira 2, situada $100 \mathrm{~m}$ a norte do kimberlito, possui também forma piriforme, com diâmetro principal de $90 \mathrm{~m}$ na direção NS. Constitui uma pequena elevação de 5 m que se destaca na topografia local, apresentando-se coberta por inúmeros blocos semi-alterados de

\footnotetext{
"Apoio CNPq e FAPESP.

Departamento de Mineralogia e Petrologia, Instituto de Geociências, USP.
} 
até $30 \mathrm{~cm}$, tornando a colina um afloramento único. Esse corpo é constituido por lavas ultrabásicas de coloração cinza com poucos macrocristais de olivina de contorno irregular em matriz afanítica. A olivina que constitui 15 a $20 \%$ da rocha, ocorre principalmente como feno e microfenocristais idiomórficos a subidiomórficos, às vezes formando glomérulos junto com espinélio e apresentando comumente geminação interpenetrante de dois indivíduos. A matriz é constituída por pequenos prismas de piroxênio com textura feltrosa e grãos de espinélio, perovskita, ilmenita (?) de maior tamanho e alguma flogopita poiquilftica intersticial. Apresenta estrutura fluidal bem desenvolvida devida à presença de lentes subparalelas de até $2 \mathrm{~cm}$ de espessura constituldas por vidro inalterado com quantidades variáveis de flogopita e anfibólio incolor poiquiliticos, diopsídio, apatita e um mineral incolor de secção hexagonal e birrefringência baixa ainda não identificado (cancrinita?, nefelina?). As lentes estão bordejadas pelo piroxênio da matriz orientado como em uma textura traquítica. Em zonas de maior concentração de lentes desenvolve-se abundante flogopita poiquilitica na matriz da rocha. Xenólitos de encaixantes são freqüentes enquanto que os mantélicos são escassos.

A intrusão Limeira 2 é circundada na parte sul por uma brecha com forma de meia lua, Limeira 3 , cuja espessura máxima não ultrapassa $30 \mathrm{~m}$. A alteração desse corpo produz um solo de cor intermediária entre a encaixante e o kimberlito, que grada para a rocha compacta a partir de $5 \mathrm{~m}$ de profundidade. Macroscopicamente, a rocha apresenta clastos abundantes de coloração branca amarelada $\Theta$, pseudomorfos de olivina preta esverdeada em uma matriz afanítica de cor cinza clara. Observações pormenorizadas mostram que a rocha é semelhante à do corpo Limeira 2, tanto no aspecto e quantidade de olivina, como na mineralogia e textura da matriz. Os clastos aparecem como fragmentos de contornos irregulares e angulosos, de composição variada, bordejados por piroxênio com textura traquftica. Alguns são de vidro criptocristalino com abundante carbonato de granulação fina; outros, raros, têm também flogopita e anfibólio; a maioria, contudo, são constituídos por agregados de zeólita rica em bário (harmotoma ?) com cristais de apatita e/ou pirita, prismas finos de anfibólio verde-avermelhado e, eventualmente, carbonato. Como observado no corpo Limeira 2, os xenólitos do embasamento são comuns, estando os mantélicos ausentes.

Os estudos realizados nos corpos Limeira colocaram em evidência relações entre kimberlitos e lavas ultrabásicas (kamafugitos?), constituindo uma associação rara no mundo. Outras intrusões semelhantes a essas têm sido encontradas na região dos municípios de Catalão (GO), Monte Carmelo e Coromandel (MG). Estudos pormenorizados, atualmente em andamento procurarão definir melhor a natureza e as relações entre esses corpos, bem como uma possível vinculação entre eles e o diamante garimpado na região. 